\title{
O Lúdico como Ferramenta para o Cuidado Humanizado com Pacientes Oncológicos Pediátricos Hospitalizados
}

\author{
Andrade, Maisa Alves; Fontes, Mírzia Lisboa; Araujo, Jamilly Santos; Almeida, Thaynara \\ Fontes; Oliveira, Patricia Gois de; Kameo, Simone Yuriko \\ Universidade Federal de Sergipe - maisinhaalves@hotmail.com
}

\begin{abstract}
INTRODUÇÃO: o diagnóstico do câncer é visto como uma doença incurável, que está ligada diretamente à morte, despertando assim sentimentos de medo, angústia e insegurança. Associada às dificuldades que a própria doença traz, as condições de hospitalização podem afetar a totalidade da criança de forma que o seu desenvolvimento físico, emocional e intelectual fiquem comprometidos. Percebe-se que muitas dessas crianças misturam realidade e fantasia durante a hospitalização e é aí que se identifica a importância da humanização do profissional de saúde, tornando-se um educador e utilizando recursos lúdicos para esclarecimento dos procedimentos. OBJETIVOS: Conhecer de que forma as atividades lúdicas contribuem para o cuidado humanizado às crianças hospitalizadas, através de revisão da literatura. MÉTODOS: Trata-se de um estudo do tipo revisão de literatura. a busca foi realizada por meio da consulta dos periódicos disponíveis nos principais banco de dados. Foram selecionados os artigos que, em seus títulos, mencionassem a palavra "lúdico", "brinquedoteca" ou "brincar em oncologia". Os artigos obtidos foram submetidos a releituras, com a finalidade de realizar uma análise interpretativa direcionada pelo objetivo estabelecido previamente e, assim, os conteúdos encontrados foram agrupados em seus aspectos históricos e conceituais. RESULTADOS: Os estudos mostram que através de jogos e brincadeiras a criança vai desenvolvendo o senso de responsabilidade, hábito de participar, observar, fazer, criar, relatar, imaginar e ir à busca de algo, pois o brincar é uma das atividades fundamentais para o desenvolvimento da identidade e autonomia da criança. o lúdico oferece oportunidades para a criança desenvolver habilidades, construir conhecimentos e socialização. no hospital a brinquedoteca contribui para quebra das características deste ambiente, voltado para diagnosticar e intervir no combate à doença. Nela a criança não se percebe como o doente a ser tratado, mas sim inserida em um ambiente alegre e descontraído, onde ela pode e até deve "fazer de conta" que é, sente ou tem que gostaria de ser, sentir ou ter no momento. CONCLUSÃO: Observou-se que o impacto causado pela brinquedoteca nos serviços pediátricos são favoráveis, inclusive quanto ao tempo de permanência, fazendo-os reagir melhor ao tratamento instituído, ajudando a amenizar traumas que podem surgir com a internação e aliviam consideravelmente a saudade de casa e da escola. para a criança hospitalizada, a brinquedoteca desenvolve o papel de terapia lúdica e permite aumentar as chances de sobrevida com qualidade. a sala de recreação também permite aos profissionais de saúde a qualificação em humanização, quanto à forma de cuidar. Os resultados evidenciam o valor do lúdico enquanto estratégia redutora de danos com desenvolvimento das potencialidades e solidificação das relações sociais além de fomentar o cuidado humanizado dentro das instituições hospitalares.
\end{abstract}

Andrade, Maisa Alves; Fontes, Mírzia Lisboa; Araujo, Jamilly Santos; Almeida, Thaynara Fontes; Oliveira, Patricia Gois de; Kameo, Simone Yuriko. O Lúdico como Ferramenta para o Cuidado Humanizado com Pacientes Oncológicos Pediátricos Hospitalizados. In: Anais do Congresso Internacional de Humanidades \& Humanização em Saúde [= Blucher Medical Proceedings, num.2, vol.1]. São Paulo: Editora Blucher, 2014. ISSN 2357-7282

DOI 10.5151/medpro-cihhs-10796 